\title{
TRIESTE È UNA DONNA: \\ WOMAN AND URBAN SPACE IN SVEVO'S SENILITÀ
}

\author{
ELENA CODA
}

\begin{abstract}
Conoscete la "saica" la bella Carintiana? Era una nave tutta di legno dolce, inventata a Trieste, che vendeva sé con tutto il carico, per non far, vuota di mercanzia e d'utilità, la strada del ritorno. Trieste è una "saica" traverso i secoli (Slataper, Lettere triestine, 12).1
\end{abstract}

Slataper's statement, taken from one of the several provocative articles he wrote in 1909 during his collaboration with the Florentine journal La Voce, captures one of the central issues that defined Trieste from the late eighteenth century until the Great War. Prior to the end of the First World War, Trieste belonged to the Austro-Hungarian Empire. Situated just outside of the newly created Italian state, the city was politically and culturally peripheral with respect to Rome and Vienna, but at the same time, as the only port of the empire, it developed into a thriving economic centre. From the eighteenth century onward it was granted the status of free port, with all the privileges and exemptions this entailed. ${ }^{2}$ As a result, Trieste attracted people

1 "Do you know the saica "La Bella Carintiana"? It was a ship made of soft wood, devised in Trieste, that sold itself with all its load so as not to make the return journey void of payload and use. Trieste is a saica [voyaging] through the centuries." Here and elsewhere, all translations from the Italian are mine, unless otherwise indicated.

${ }^{2}$ One should not think that the fact that the city was thriving economically meant that it was also an important cultural or political centre. The historian Elio Apih has already commented on the cultural marginality of Trieste at the turn of the twentieth century: "alla grande crescita del porto adriatico non corrispondeva un adeguato sviluppo di istituzioni, e la città resta periferica rispetto ai grandi centri produttori di cultura [...]; chi in quegli anni nasceva letterato doveva cercare il suo prestigio civile rifacendosi alla tradizione culturale italiana come tale, alla kulturnation (è a questa tradizione, non a quella locale che fa riferimento lo pseudonimo emblematico di Italo Svevo). È per riallacciarsi a questa tradizione che la nuova generazione intellettuale va a Roma e a Firenze." Apih, Trieste, 96. See also Ara and Magris, Trieste, 3-17. 
from different countries, conferring upon the city a unique cosmopolitan flavour. In the words of the Triestine poet Umberto Saba:

Il suo incanto maggiore stava nella sua varietà. Svoltare un angolo di strada voleva dire cambiare continente. C'era l'Italia e il desiderio dell'Italia, c'era l'Austria (mica poi tanto cattiva come si pensava), c'era l'Oriente, c'era il Levante con i suoi mercanti in Fez rosso, e molte altre cose ancora (Saba, Prose, 215-216).

(Its major enchantment lay in its variety. Turning a corner meant changing continents. There was Italy and the desire for Italy, there was Austria (not really as bad as we thought), there was the Orient, there was the Levant with its merchants with red Fez, and many other things still.)

The Italian Triestines were well aware that their economic prosperity was contingent on their city's political dependency on the Central Powers, yet they also believed that the city should belong to Italy, to which they felt strong cultural and national ties. The image of Trieste as a prostitute-as a body caught between national, ethnic, and economic interests that must compromise its national identity in order to achieve economic prosperity-becomes for the Triestine writers of the turn of the twentieth century an emblem for the crisis of the Triestines themselves: they must recognize and accept that their geographically marginalised position and their politically ambivalent situation are not a hindrance, but in fact assets to their economic success and intellectual pursuits. The uniqueness of this city is the reason why it becomes, for authors such as Umberto Saba (18831957), Italo Svevo (1861-1928), and Scipio Slataper (1888-1915), a space of constant inspiration and meditation.

Before the great modernist novels by Rilke, Proust, Joyce, or Musil, Italo Svevo, whose real name was Ettore Schmitz-a citizen of the AustroHungarian Empire, a non-practising Jew of German ancestry, Italian by language and political sympathies-reflects in his novels on the inherent contradiction of the modern human condition as it unfolds on the streets of Trieste. The poet Eugenio Montale was the first to point out that in Svevo the city of Trieste is much more than a simplistic geographical background against which action can occur, but becomes in fact,

un personaggio-città [. . . ] segreta matrice di fatti e di situazioni, luogo piuttosto metafisico che geografico o geometrico di scontri che un diverso scenario renderebbe diversi e senza dubbio meno significativi. [...] città di traffico ma anche città d'anime, città simbolica non meno della Praga di Kafka e della Dublino joyciana, questa è già la Trieste del primo Svevo. ${ }^{3}$

${ }^{3}$ Montale, "Preface" to Svevo, La coscienza di Zeno, n.n. 
(a character-city [...] a secret matrix of facts and sittuations. Rather than [simply] a geographical or geometrical space, [Trieste is] a metaphysical setting of tensions that a different place would have made different and, without a doubt, less meaningful. A commercial city, but also a city of souls, Trieste, as represented in the early works of Svevo, is already a symbolic city, just like Kafka’s Prague and Joyce's Dublin.)

In Svevo's second novel, Senilità (1898), Montale continues, Trieste becomes "la trama stessa, necessaria, insostituibile" (the plot itself, necessary, irreplaceable). 4

Svevo does more than just bring to the fore the geographic setting of his novels. In Senilità he links directly the urban experience to the female figure by introducing one of his most interesting and fascinating characters: the beautiful, morally ambiguous, elusive, and laughing Angiolina Zarri, a young proletarian woman who comes to symbolize the labyrinthine, uncontrollable structure of the city itself. The aim of this article is to show that by pursuing a critical path that follows Angiolina's irreverent and elusive laughter, we will be able to understand the author's intentions in this novel. I will argue that through her laughter Svevo explores a new way to approach the modern urban environment.

The plot of the novel is easily summarized: it narrates the story of Emilio Brentani, a thirty-five year old bachelor with literary aspirations who works as a clerk for an insurance company and lives with his younger sister Amalia, a grey, silent figure who has devoted her life completely to her brother whom she cares for like "a selfless mother." However, Brentani's monotonous equilibrium is shattered once he meets Angiolina Zarri. Emilio chooses to pursue Angiolina because he believes that he would not be compromised by a relationship with her (given the low social status of the girl) and because he is certain that he will be able to use her as he pleases. "I like you a lot, but you could never be more than a plaything in my life" ("Mi piaci molto, ma nella mia vita non potrai essere giammai più di un giocattolo") 5 is the unspoken sentence at the beginning of the novel that informs the reader of Emilio's attitude towards the young woman. Angiolina's entrance in Emilio's life will not only disrupt his quiet existence (as he becomes increasingly jealous of the young woman), but will also destroy his household. Once Amalia perceives Emilio's passion for

${ }^{4}$ Following Montale's intuition, many critics have analysed the ways in which Svevo portrayed Trieste in his novels: Angelo Ara and Claudio Magris noted that Svevo is the poet of the bourgeois condition and its crisis and Trieste "lo scenario ideale" in which this crisis can take place. See Ara and Magris, Trieste, 4.

${ }^{5}$ Svevo, Emilio's Carnival, 1; Senilità, 9. 
Angiolina, she becomes aware of her own alienated existence and tries to compensate for the sense of emotional emptiness that she feels by falling in love with Stefano Balli, Emilio's best friend. Balli, an unsuccessful artist but very successful womanizer, shows no interest for Amalia; once he finds out about her secret love for him, he refuses even to visit the Brentanis' home. This drastic rejection precipitates Amalia's illness and eventual death. Angiolina, on the other hand, disappears and Emilio later discovers that she has fled to Vienna with a dishonest bank clerk. Abandoned by Angiolina and his sister, Emilio perpetuates their memory by creating in his mind an image of a new Angiolina who combines both female figures: Angiolina maintains her beauty but loses her laughter in order to become serious and sad like his sister.

In this narrative scheme, the loss of Angiolina's laughter in Emilio's imagination is more significant than might at first appear. However, traditional approaches to the novel have paid little attention to the role of Angiolina and her laughter, perhaps because the actions of the novel's characters are so tightly intertwined that to analyse them separately might appear to be a difficult task. Moreover, because the story is narrated for the most part from Emilio Brentani's point of view, we know Amalia, Angiolina, and Stefano Balli only through his eyes. ${ }^{6}$ This apparently unilateral perspective of the novel has misled critics to focus mostly on Emilio Brentani, while the analysis of Angiolina has been peripheral at best, despite her conspicuous presence throughout the story.

Key elements brought to the fore by critics of Senilità are Emilio's ineptitude in controlling external events and his sense of resignation.? Saccone's analysis of Brentani is particularly interesting: for him Emilio represents the modern existential hero who, in a world without God, is still searching for an authentic existence. In this interpretation, the quest for authenticity assumes political and social overtones at the end of the novel when Emilio dreams of a world that can transcend the tensions and antagonism of modern life by offering social justice. ${ }^{8}$ From another angle, the novel has also been read as a critique of bourgeois existence, in which an individual's actions are dictated purely by self-interest. In his design to

GSaccone, Il poeta travestito, 184-185.

7 Arcangelo Leone De Castris notes for instance: "Emilio diventa l'eroe di un'esistenza debole e sconvolta dagli eventi, eppure senza pretese, dolente. Non nutre fermenti grossolani di ribellioni titaniche, ma dolorosamente incontra il quotidiano problema del vivere, a cui si rassegna, vivendo." Leone De Castris, Italo Svevo, 124.

${ }^{8}$ Saccone, Il poeta travestito, 196-200. 
seduce Angiolina without ever assuming the risk of compromising himself, Emilio embodies the bourgeois world of self-absorption.? The irony of the novel resides in the fact that ultimately the joke is on Emilio, for by falling in love with Angiolina he becomes devoured by jealousy and is therefore unable to treat her as the toy he thought she was. ${ }^{10}$

In these critical explanations of the novel, Angiolina remains in the background, perceived only as the catalyst for the events narrated. For Saccone, Angiolina is important only indirectly because she brings out Emilio's incapacity to have a sincere relationship and because she undermines the reassuring universe he has created for himself, constituted by his home and his work; Angiolina is only a "civetta" who tries to fulfill a bourgeois dream by finding a man who will allow her to improve her social status. ${ }^{11}$ Barilli sees her as little more than a prostitute, a woman who lives day by day seizing all she can while in the long run she is condemned to a destiny of perdition. ${ }^{12}$ Finally, for Laura Benedetti, Angiolina is the embodiment of the "donna peccato" whose role in the novel is simply to represent Emilio's erotic drive. ${ }^{13}$ More generous is the judgement of Bruno Maier, who sees her as an emblem of health and vivaciousness. ${ }^{14}$

Although these readings of Angiolina give us a glimpse of her character and Emilio's relation to her, they do not adequately explore Angiolina's importance in the novel. I believe that by situating the novel within the broader context of late nineteenth-century cultural and urban studies, it will become clear how subversive this female character really is.

${ }^{9}$ See, for instance, the following remark made by Emilio at the beginning of his love affair, related by Svevo in free indirect discourse: "Egli s'era avvicinato a lei con l'idea di trovare un'avventura facile e breve, di quelle che egli aveva sentito descrivere tanto spesso e che a lui non erano toccate mai", Senilità, 11 (He had approached her with the notion of a casual and brief adventure, like those he had so often heard described but which had always eluded him", Emilio's Carnival, 3).

10 Borghello, La coscienza borghese, 112-117.

11 Saccone, Il poeta travestito, 173.

12 Barilli, La linea Svevo-Pirandello, 81.

13 Benedetti, "Vivere e essere vissuti: Amalia in Svevo's Senilità," Italica, 68 (1991) 204-216.

${ }^{14}$ Bruno Maier writes: "Lo Svevo ha intuito e rappresentato perfettamente la psicologia di questa ragazza che ignora il senso del mistero, le sottili arti della seduzione, il sofisticato demonismo della cocotte di classe, ed è riuscita a serbare in sé una simpatica e allegra vivacità, una gaia e tutta effusa franchezza popolaresca [...]; e ci ha dato una delle figure più "vere" [...] della narrativa dell'ultimo secolo." Maier, Italo Svevo, 80. 
In late nineteenth-century Europe, both city and woman were seen as sources of anxiety. The growth of cities into metropolises invited philosophers and sociologists to ponder the destiny of individuals living within the urban environment. Sociologists such as Ferdinand Tönnies, Georg Simmel, and Max Weber saw the city as a dehumanizing space in which human relations were reduced to their exchange value. In 1887, Tönnies argued in Community and Society that the loss of a sense of community within the rationalized and impersonal urban space led city-dwellers to feel alienated and uprooted from the environment in which they lived. For Tönnies, moreover, this was a void that could never be filled. For many sociologists in the late nineteenth century, nostalgia for an existence within an organic community was one of the particular traits of modern life.

Particularly interesting in this regard is Georg Simmel's study The Philosophy of Money, first published in 1900. Here Simmel constructed a socioeconomic theory that posits the act of money exchange as the pivot around which all social relationships develop. Simmel highlighted the objectification and mechanization of economic transactions, and argued that the individual in a mature money economy becomes a mere "representative or executor of these [economic] determinants which lie outside himself" (79). Moreover, individuals are not immune to this process of objectification which leads them to reduce every human interaction into a thing-thing relation. Thus, for Simmel a money transaction should not be understood simply as an economic fact, but should be "treated as a psychological fact, or as one that derives from the history of morals or even as an aesthetic fact" (55). In other words, economic interactions become for him the object of a philosophical inquiry that emphasizes "the ultimate values [...] in all that is human" (55). The philosophical concern about the rationalistic character of contemporary life, where everything is reduced to its exchange value, is further developed in the essay "The Metropolis and Mental Life", later anthologized in the volume On Individuality and Social Form. Here Simmel underscores the role that rationalization and objectification plays in the metropolis. He perceived urban life as dominated by nervous impulses that bombard and disorient the individual. The only resource available to human beings trapped within this overwhelming multiplicity of stimuli, he theorized, was their intellectual capacity to rationalize their urban experiences and reduce them to tangible values. Therefore, in the metropolis qualitative relations are transformed into quantitative ones. In this system, money becomes the "frightful leveller-it hollows out the core of things, their peculiarities, their specific values and their unique- 
ness [...] in a way which is beyond repair" (330). The psychological result of this objectification is what Simmel calls the "blasé attitude," that is to say, "an indifference towards the distinction between things" (329). For the blasé individual, both people and things acquire value only as commodities that can be exchanged.

One of the major consequences of a world ruled by the money economy is that it is always driven towards new markets. As a result, the characteristic force that rules the metropolis is centrifugal in nature. As Massimo Cacciari noted in his study of the metropolis, in a world that by its very nature moves away from its centre, it becomes impossible to attempt to order and express the urban experience as one coherent cultural expression. This is the crisis that the intellectual of the metropolitan experience must face: the metropolis denies the possibility of synthesis. It remains impossible to grasp, fluid, and uncontainable. The intellectual who persists in wanting to give a synthetic form to the metropolitan experience is, therefore, "un mistificatore, in modo programmatico, della realtà del rapporto sociale dato" (41; "a programmatic mystifier of every given reality"). It is not difficult to see how Trieste-the city emporium, with commercial ties that extend from Asia to the Middle East to Central Europe, the site of a thriving exchange market-conformed to the image of the modern metropolis we have just explored.

If, on the one hand, sociologists and cultural critics are concerned about the mechanization and intellectualization of urban life, on the other hand they become increasingly anxious about the role that women play within the city: women become the object of sociological, medical, and philosophical studies which attempt to identify how the sexes respond to the modern environment. ${ }^{15}$ It is not by chance that throughout his career Simmel wrote also a large number of essays dedicated to female psychology, love, feminine culture, and the relationship between the sexes. Simmel's writings are representative of one of the two broad opposite views that developed at this time in regards to women's role within modern society. Simmel sees woman as a whole, organic, coherent entity who is therefore completely alien to the fragmentation and alienation that prevails in the modern experience. In his essay "The Relative and the Absolute in the Problem of the Sexes" (1911), he clearly underlines how "woman is always

\footnotetext{
${ }^{15}$ Elaine Showalter in her study Sexual Anarchy and Culture at the Fin de Siècle, notes that at the beginning of the twentieth century conventional definitions of masculine and feminine were questioned and challenged by changes in the society, leading to "cultural and sexual anarchy"; 3 .
} 
at home with herself while the man has his home beyond himself" (Simmel, George Simmel on Women, 116). The sense of alienation that man feels is the driving force that pushes him to participate in the modern experience, in an effort to regain that sense of completion that he is lacking. In contrast, because woman does not need to overcome a rupture that for her does not exist, she does not feel the need to participate in the process of modernity. As Rita Felski states in her important study of women in modernity, Simmel here proposes an idea of femininity as "radical nondifferentation:" "in contrast to male becoming, woman represents being; whereas he is dynamic, she is beyond historical time. The center and periphery of female existence are integrated into a harmonious synthesis, the ultimate example of a selfcontained plenitude. [...] Homogenous and whole, woman is presented in Simmel's text as serenely free of alienation and contradiction, as the very opposite of the split subject" (45-49). ${ }^{16}$ Following the same line of thought, the Italian physiologist and anthropologist Paolo Mantegazza argued in his Il Secolo Nevrosico (1887) that a woman's logical place is the home: the role of women is to recreate within their household that sense of coherence and security that is lost in the outside world.

However, this is not the only way in which women were understood at that time. In opposition to Mantegazza and Simmel, thinkers such as Cesare Lombroso, Max Nordau, and Otto Weininger perceived women-especially the women who left the privacy of their home to take part (as a prostitute or as a worker) in the urban experience-as both mysterious and threatening. ${ }^{17}$ These thinkers perceived women to be domi-

16 See also van Vucht Tjissen, "Women between Modernity and Postmodernity," 147-163.

17 Philosophers and cultural critics such as Max Nordau and Otto Weininger used the medical research on degeneration conducted by Cesare Lombroso to analyse different aspects of urban culture. In spite of their specific interests, they identify the city as the major cause of the propagation of neurasthenia-traditionally linked with the feminine-which is seen as the primal cause of degeneration, defined, in the words of Nordau as the breakdown of the established order and "a contempt for traditional views of custom and morality" (5). According to their writings, life in the city suffocates one's individuality; moreover, the fragmentary and chaotic urban experience restrains the city-dweller from achieving a harmonious and healthy sense of self, making the individual susceptible to mental and physical illnesses. The modern city becomes for these writers the indisputable site of everything that is considered negative and sick: weakness, femininity, decadence, and ambivalence are all different symptoms of the same urban disease. See Lombroso and Ferrrero, La donna delinquente, la prostituta e la donna normale, 1893; Nordau, Degeneration [1892], 1993; Weininger, Sex and Character, 1906. 
nated by their sexuality, a fact that not only distracted them from higher spiritual and intellectual achievements, but that also led them to moral debasement and depravation. As a result, women were deemed incapable of living complete and coherent lives. Moreover, since women changed opinions and ideas constantly they were viewed as uncontrollable. In his phrenological studies on women, Lombroso created a detailed moral and physical portrait of different types of women in an attempt to categorize and distance the threat that they represented to urban society.

In the nineteenth-century imaginary, the negative, threatening traits that characterized women were often linked to the urban phenomenon of crowds in order to give voice to and exorcize the fear of a disruption of traditional social order. ${ }^{18} \mathrm{~A}$ case in point is the study on crowds by the social psychologist Gustave Le Bon. In his examination of this urban phenomenon, Le Bon compared the threatening characteristics of crowds to what were considered typical feminine traits. He noted for example that crowds are controlled by "impulsiveness, irritability, incapacity to reason, the absence of judgment and of critical spirit which are almost always observed in [...] women" (35-36). The only way to maintain control over the tendencies of woman and the crowd alike (and, consequently, of the urban environment in which both moved) was to reduce them to the object of scientific studies. Under the authoritative gaze of scientific discourse, woman and crowd lost their autonomy and threatening qualities, and became more manageable.

The concept of flaneur as brought forth by Baudelaire and later developed by Walter Benjamin, offered a different vision of the city and its crowds. ${ }^{19}$ Yet the flaneur, the man of the crowd, who is at home in the streets and is able to give poetic voice to the ephemeral and transient experiences of urban life, is a predominantly male subject. His power of observation is precluded in his feminine counterpart. As Deborah Parsons notes in her book on women and the modern city, even while the female figure-as prostitute or as passante-occupies a predominant space in Baudelaire's work and fascinates the poet because she "exhibit[s] similar characteristics to male urban observers," (24) she is denied the power of observation and is rendered completely passive by the author's gaze. Although an integral part of the urban space, she never becomes an active participant in it. According to Parsons, in fact, turn-of-the-century male writers emphasized the role of women in the urban space only in order to "define [themselves] out of a society that was uncontrollable and thus

18 See also Parsons, Streetwalking the Metropolis, 43-81.

${ }^{19}$ See Baudelaire, Selected Writings, and Benjamin, Charles Baudelaire. 
abhorrent, both the product and the consumer of the commodity world being described as feminine" (38).

It is by keeping in mind the ways in which woman and city had been perceived at the turn of the century that it is possible to understand Svevo's innovative representation of a woman in Senilità. Angiolina reflects the essence of Trieste. Both occupy a marginal space in relation to the established power: just as Trieste is geographically and politically peripheral to the Austro-Hungarian Empire so Angiolina, a young proletarian woman living at the end of the nineteenth century, is a marginal figure in a bourgeois society still dominated by men. However, the fact that they are both able to function and thrive within their particular milieu-underscores the notion that what is considered ex-centric -ex centro, literally displaced, outside the centre- becomes, for Svevo, the key to approaching the modern experience. ${ }^{20}$

Not only does Angiolina's elusive character resemble a labyrinthine urban space, but she also becomes the only possible answer to it. The ways in which Svevo presents and then undermines both Emilio's view of Angiolina (by presenting a figure who escapes his facile categorization) and Balli's attempt to give her an aesthetic form, make it clear, in fact, that the author does not subscribe to the ways in which the two male characters respond to reality. On the contrary, through the character of Angiolina Svevo is interested in expressing an alternative and more playful way to interact with the urban environment.

Svevo here puts forth what Nietzsche in the Gay Science calls "the eternal comedy of existence" (75). In the first chapter of his book, the German philosopher notes with dismay that "[f] or the present we still live in the age of tragedy, the age of moralities and religions" (74). We are at the mercy of "these great tragedians" who take the stage to dictate what is right or wrong, promoting that there is a grounding meaning to existence that gives purpose to our lives. However, he continues, "there is no denying that

${ }^{20}$ In an essay entitled "L'eccentricità e l'ex-centricità dei protagonisti sveviani" Corrado Federici uses the concept of ex-centricity to describe Emilio and Zeno in an attempt to situate them within a postmodern aesthetic. For Federici, Emilio is ex-centric in as much as he remains at the margin of the established bourgeois society (Federici, "L'eccentricità," 51-62). In using this term, it is not my intention to analyse possible post-modern implications of the text, but to link instead the centrifugal experience of the modern metropolis with the character of Angiolina. 
in the long run every one of these great teachers of existence was vanquished by laughter" (75; italics in the text). Still, "[i]n spite of all this laughter" human nature has changed so much that now it cannot survive without them. Here lies the paradox of human existence: the individual strives to find meaning, depth, or purpose in life while instead life should be embraced and joyfully accepted for its meaninglessness, purposelessness, and spontaneity. There is no essence behind appearance, and this is the only truth that we should cherish. Moreover, Nietzsche links truth as appearance, as surface, to woman: "perhaps truth is a woman who has reasons for not letting us see her reasons?" (38) ${ }^{21}$ In her book Breaking Up [at] Totality Diane Davis eloquently summarizes Nietzsche's proposition, " "Truth " is a woman who has not been won, laid bare, by the "gruesome seriousness" of dogmatic philosophers. She has eluded their grasps" (174). Furthermore, Davis notes how this notion has been appropriated by feminist theorists such as Irigaray and Cixous, who have underscored that a feminine voice can be found only by overcoming altogether the dichotomous structure of logocentric law. ${ }^{22}$ Thus, Irigaray's notion of woman as fluidity that resists imprisonment by "the framework of the ruling symbolic," (106) or Cixous' intuition of woman as being already "elsewhere," (893) become pivotal for a reformulation of a feminist praxis "that moves beyond a desire for mere subversion" (164). In this theoretical frame,

${ }^{21}$ Nietzsche points out that ancient Greeks had already grasped this secret: "Oh, those Greeks! They knew how to live." From them we should also learn "to stop courageously at the surface [...] to adore appearance, to believe [.. .] in the whole Olympus of appearance" (38).

${ }^{22}$ Luce Irigaray asks for instance: "how can women analyse their own exploitation, inscribe their own demands, within an order prescribed by the masculine? Is a women's politics possible within that order? What transformation in the political process itself does it require?" and remarks that when women's movements "aim simply for a change in the distribution of power, leaving intact the power structure itself, then they are resubjecting themselves, deliberately or not, to a phallocratic order" (This Sex Which Is Not One, 81; italics in the text). Hélène Cixous, revisiting Nietzsche's master-slave proposition, notes how much feminism is still imprisoned by a reactionary chain based on resentment. Thus, "[i]f the New Women [...] dare to create outside the theoretical, they're called in by the cops of the signifier, fingerprinted, remonstrated and they are brought into the line of order that they are supposed to know; assigned by force of trickery to a precise place in the chain that's always formed for the benefit of a privileged signifier. We are pieced back to the string which leads back, if not to the Nameof-the-Father, then, for a new twist, to the place of the phallic-mother" (The Laughter of Medusa," 892). 
laughter both provokes and occupies, for Davis, the destabilizing space that "occurred in the shattering of the either/or choice" (208).

Going back to Svevo's beautiful and laughing Angiolina, I would argue that her bursts of laughter operate in a similar manner: they shatter the rigid world view of the two male characters and underscore the possibility of a feminine "elsewhere" that escapes the entrapment of masculine order. From a narrative perspective, by presenting a character that eludes Emilio's perception, Svevo questions the possibility of having a monological understanding of reality. In the modern urban space one's consciousness is not enough to filter the complexities of contemporary existence. It might have been enough if, as Luigi Pirandello tells us in Il fu Mattia Pascal (written almost two decades after Svevo's Senilità), one lived isolated as if in a castle. In the contemporary world, however, the centralized image of the castle has been replaced with that of the piazza - the open square, the marketplace-in which every individual must constantly interact with other human beings and respond to an infinite number of external stimuli (Pirandello, Il fu Mattia Pascal, 97-98). What is interesting in this new interpretation of reality is that no individual can assume a central position. In the square, as in the metropolis, relationships and interactions remain fluid, open, and dynamic. Like Pirandello, Svevo understood well the importance of these characteristics in contemporary life-this is why he chose the novel as the genre better suited to express these elements. In fact, as Mikhail Bakhtin noted in The Dialogic Imagination, the novel "reflects the tendencies of a new world still in the making" (7) which is open-ended and fluid and must take into account the plurality of consciousness that inhabit and interact in it. Angiolina's presence is essential to the construction of a novel that is interested in expressing a polyphonic, multifaceted perception of urban reality, in which characters escape any definition that attempts to define them from without. ${ }^{23}$

Right from the start of the novel the relationship between Angiolina and Emilio is closely connected to the urban environment in which the narrative takes place: they meet on a busy street, where she "accidentally" loses her umbrella and he picks it up and returns it to her. And the city itself, from the bourgeois città nuova to the poorer città vecchia, from the piers to the plateau of the Carso that surrounds it, becomes the setting of all of their encounters: "amarono in tutte le vie suburbane di Trieste" ("they embraced in all the suburban streets of Trieste"). ${ }^{24}$ With Angiolina, Emilio abandons the security of the monotonous life that is defined by the closed

\footnotetext{
23 Bakhtin, Problems of Dostoevsky's Poetics, 47-49.

${ }^{24}$ Svevo, Senilità, 27; Emilio's Carnival, 18.
} 
spaces of his home and office, and enters the disorienting world of the city. However, as his affair with Angiolina deteriorates and he becomes aware of his inability to control her, he also loses his bearing within an urban environment that reveals its labyrinthine qualities and becomes more and more threatening. Svevo here uses the image of the labyrinth as a metaphor for the feeling of disorientation and loss that characterizes the modern urban space. ${ }^{25}$ As we will see, even his home, the last nostalgic bulwark in which the urban dweller believed it was possible to exist harmoniously, is not spared by the centrifugal, labyrinthine force of the city.

What Emilio fails to understand right from the beginning of the novel is how mysterious and unreadable Angiolina is. Seduced by her beauty and health, Emilio is quite unsure how to interpret the "umbrella accident." Although it appears that she dropped it on purpose, with the clear intention of being noticed and approached, Emilio is too embedded in the traditional nineteenth-century idea of health as an expression of moral rectitude to be able to dwell upon a possible discrepancy in Angiolina's persona. Had he done so, he would have perceived her incongruous essence. "[A]i retori, corruzione e salute sembrano inconciliabili" (Senilità, 12; "To rhetoricians, moral corruption and health always seem irreconcilable") is Svevo's ironic comment on Emilio's dilemma. After a first moment of puzzlement, the protagonist ends up charmed and bewitched by the woman's mysterious beauty: "infine si incantò ad ammirare una faccia misteriosa dalle linee precise e dolci" (Senilità, 12; "in the end [he] became so entranced in his admiration of a mysterious face whose contours were both lovely and well defined" Emilio's Carnival, 3). The choice of the verb "incantarsi" ("to be in awe") brings to the fore Emilio's passivity throughout the novel and, by contrast, Angiolina's active role. Emilio's belief that his affair with Angiolina will be brief and inconsequential, and that he will be able to control it and dismiss it as he pleases, is therefore revealed from the start to be a vain illusion. Moreover, in order to crystallize his fantasy into a concrete form and dispel his doubts about Angiolina's character, Emilio transforms the beautiful, elusive, laughing, and sexually charged Angiolina into his own creation: the idealized and refined "Ange" who, unlike the real Angiolina, can be moulded according to his desires. Talking to his friend Balli about her affected speech and the way she carries her

${ }^{25}$ As Wendy Faris noted in her study on literary labyrinths, the labyrinth becomes a favoured literary topos in modernist texts to "reflect the decentered configuration of the modern city. Thus, they do not represent escapes from, but rather affirmations of entrapment in the city and its languages." "The Labyrinth as Sign," (38). On literary labyrinths see also Cipolla, Labyrinth. 
head slightly tilted on one side, he states for example:

Prima o poi [...] le leverò tale difetto che mi infastidisce. [...] Segno di vanità, secondo il Gall - osservava Emilio, e con la serietà di uno scienziato che fa degli esperimenti aggiungeva: - Chissà che le osservazioni del Gall non sieno meno errate di quanto generalmente si creda? (Senilità, 40) "Sooner or later [...] I will rid her of that pretense which I find so annoying. [...] A sign of vanity according to Gall" Emilio remarked, with the gravity of an experimental scientist, adding "Who knows whether Gall's observations are more accurate than is generally believed? [Emilio's Carnival, 31])

Emilio pretends to be able to exercise his influence over Angiolina (although he is never able to convince his friend) and goes as far as to discuss her as a scientific experiment. His comments on the plausibility of phrenological theories, represented here by Gall, who founded the pseudoscience that would later be popularized by the work of Cesare Lombroso, demonstrates how much Emilio subscribes to the traditional discourse on health and morality popular at the turn of the century. ${ }^{26}$ As a consequence, the fact that Angiolina is splendidly healthy is used by Emilio to negate the possibility of questioning her moral character. In this way he tries to give a scientific proof upon which to rest his idealization of "Ange, "thus eliminating her contradictory qualities.

Emilio insists on this illusion by comparing his relationship with the young woman to a bucolic image of peace and quiet:

Amante delle immagini, egli vedeva la propria vita quale una via dritta, uniforme, traverso una quiete valle; dal punto in cui egli aveva avvicinata Angiolina la strada si torceva, deviava per un paese vario d'alberi, di fiori, di colli. Era un piccolo tratto e si discendeva poi a valle, alla facile via piana e sicura, resa meno tediosa dal ricordo di quell'intervallo incantevole, colorito, fors'anche faticoso (Senilità, 38-39).

(Fond of images, he saw his life as a perfectly straight road running through a peaceful valley. From the time he first approached Angiolina, the road began to turn and wind through a varied landscape of trees, hills and flowers. It was only a short stretch, then it dropped back into the valley, to the flat, safe, uneventful road that was made less boring by the memory of that charming, colorful, perhaps even exhausting interlude. [Enilio's Carnival, 30])

This passage must be understood in its ironic intentions. Emilio's affair with Angiolina is consummated in the city, and could not happen any-

${ }^{26}$ On the history of phrenology see Gilman, Disease and Representation, 32-39. 
where else because Angiolina is indisputably a creature of the city: she belongs to the proletarian class that became one of the predominant features of urban life at the turn of the last century. Yet Emilio's imagination leads him to visualize his affair in a less threatening environment: a beautiful country landscape. The fact that even rhetorically he must distance his love affair from its realistic urban setting by pretending that it will lead him to a rural scenery not only foreshadows Emilio's inadequacy in managing the urban space in which Angiolina moves, but, most importantly, it underscores his inability to formulate images that escape banal literary clichés. Emilio sees himself as a genial writer, whose great literary accomplishment is still in the making, "come una potente macchina geniale in costruzione, non ancora in attività" (Senilità, 11; "[as] an ingenious mechanism of great power, not yet functioning but still under construction" Emilio's Carnival, 2) and he envisions the young woman as his inspiring muse. ${ }^{27}$ However, the moment he has to conjure up an image to express his new adventure, he is unable to do so without invoking a very trite picture of a pretty landscape that he might have borrowed from one of the many sentimental novels his sister Amalia devours during her long and lonely days. In this passage Svevo reveals that Emilio is both emotionally and intellectually unequipped to deal with his new urban experiences. Throughout the novel, his attempts to create a literary work inspired by his affair with Angiolina will never materialize because he does not possess a language for it. Of course, Emilio's vision is partially correct: Angiolina will make him lose his sense of direction. But the adventure Emilio embarks on will not lead him to a bucolic "intervallo incantevole"; it will take him instead right into the streets of Trieste.

Emilio's idealization of Angiolina gives him the illusion of being able to manage her and is parallelled by his attempt to maintain a distance from the city. In fact, his favoured places for their romantic encounters are isolated, away from the crowded streets. During one of their first rendezvous, they walk to Opicina, a small village located on the plateau that surrounds Trieste. Yet, in spite of the distance and the advantageous view that it offers of the city below, Emilio is unable to perceive Trieste in its distinct forms

27In front of Angiolina, Emilio "ebbe il sentimento che da tanti anni non aveva provato, di comporre, di trarre dal proprio intimo idee e parole: un sollievo che dava a quel momento della sua vita non lieta, un aspetto strano, indimenticabible" Senilità, 11 ("He had the sensation, not experienced in years, of composing, of extracting ideas and words from deep within himself. A sense of relief endowed that moment of his unfulfilled life with a strange unforgettable quality of repose, of peace" Emilio's Carnival, 3). 
and contours:

muta, morta, come il mare, di lassù nient'altro che una grande estensione di colore misterioso, indistinto: e nell'immobilità e nel silenzio, città, mare e colli apparivano di un solo pezzo, la stessa materia foggiata e colorita da qualche artista bizzarro, divisa, tagliata da linee segnate da punti gialli, i fanali delle vie. La luce lunare non ne mutava il colore. Gli oggetti dai contorni divenuti più precisi non si illuminavano, si velavano di luce (Senilità, 27).

(still, silent, like the sea, stretched out below their feet. From up there it looked like little more than a vast expanse of some indeterminate mysterious color. And in the silence and the stillness, city, sea and hills seemed all of a piece, the same material molded and colored by some weird artist, divided into sectors, divided into sectors by the dotted yellow lines of the streetlamps. Moonlight did nothing to alter the color. Objects whose contours became clearer were not so much illuminated as veiled by light. [Emilio's Carnival, 18])

From above, the city appears menacing to Emilio: its distance and silence are not comforting, but make it seem an unfamiliar place, surrounded by an aura of mystery and indifference, as suggested by the use of the adjectives "silent" and "dead." From afar, Trieste appears divided; rather than bringing clarity to the city, the street lights distort its image, cut it up-revealing, in this way, its lack of unity. The image that derives from this description is that of an unreal city, created by some eccentric painter. Even the moonlight is unable to illuminate the city below; instead, it has the opposite effect: the use of the verb "to veil" to describe the effect of the moonlight on the city underscores the fact that the city remains concealed, and thus undecipherable. ${ }^{28}$

If the lunar light has the effect of bringing to the fore the city's unsettling qualities, it would seem that it has the opposite effect on Angiolina. Surrounded by the white moonlight, she appears in Emilio's eyes as chaste and pure, "baciava la casta, bianca luce" (Senilità, 28). Yet, this image is contrasted in the following paragraph when Emilio realizes that Angiolina is an experienced kisser and might very well be less innocent than he imagined. In the same way that the city remains unsettling even from above (although the advantageous point of view should allow him to compre-

\footnotetext{
${ }^{28} \mathrm{On}$ the perception of the cityscape, see Frisby, Cityscapes of Modernity. The chapter "The City Dissolved," in which the author examines the differences between the impressionistic and expressionistic vision of the city, is of particular interest. Emilio's favoured view of Trieste from above implies an impressionistic perception of the urban environment.
} 
hend it in its totality), Angiolina too reveals her ambiguity (and, ultimately, her ability to elude Emilio's grasp) precisely at the moment when he tries to possess her.

Once the urban environment becomes the locus of their affair, the ambiguity of the city and of Angiolina, which here are seen as potential threats, merge together. In the city, not only is Emilio faced with the fact that Angiolina's elusive character escapes his controlling mind, but he also becomes aware that she cannot be reduced to an object of desire. She defies the traditional role of women as objects of the male gaze by casting gazes of her own; during their walk along the Corso, Trieste's fashionable street, she enjoys attracting the attention of passers-by as much as she loves to look back at them. In this way, she is transformed from the passive object of Emilio's desire to an active observer:

Evidentemente ella aveva nell'occhio per ogni uomo elegante che passava, una specie di saluto; non guardava, ma vi brillava un lampo di luce. Nella pupilla qualche cosa si moveva e modificava continuamente l'intensità e la direzione della luce. Quell'occhio crepitava! (Senilità, 47)

(There was no doubt, her eyes extended a kind of greeting to every welldressed man who passed; she did not look at them, but there was a flash of light in her eyes. Something moved in her pupils and continuously modified the intensity and direction of the light. Her eyes sparkled! [Emilio's Carnival, 38])

Angiolina performs a truly subversive act. As Judith Butler notes in Gender Trouble, "for the masculine subject of desire, trouble became a scandal with the sudden intrusion, the unanticipated agency, of a female 'object' who inexplicably returns the glance, reverses the gaze, and contests the place and authority of the masculine position. The radical dependency of the masculine subject on the female 'Other' suddenly exposes his autonomy as illusory" (xxvii-xxviii). The way in which her gaze is described, moving constantly from man to man, shifting its depth of focus, can be seen as a camera that avidly registers and absorbs different images, reducing them to a pile of undifferentiated objects. On the Corso, Angiolina becomes a true feminine version of Baudelaire's flâneur: she rejoices in the urban spectacle where she is both observer and reflection. ${ }^{29}$ It is this abili-

${ }^{29}$ In his essay "The Painter of Modern Life" Baudelaire compares the flâneur to "a mirror as vast as this crowd; to a kaleidoscope endowed with consciousness which with every one of its movements presents a pattern of life, in all its multiplicity, and the flowing grace of all the elements that go to compose life" (Baudelaire, Selected Writings, 400). 
ty of hers to play both roles simultaneously that subverts the traditional binary role of subject/object and disorients Emilio, who realizes how illusory his power over Angiolina really is. Indeed, his meek and embarrassed attempt to reproach her active gaze is dismissed with unashamed laughter- "Ho gli occhi per guardare io," she retorts (Senilità, 47; "I have eyes for looking, I do." Emilio's Carnival, 39). Whereas Angiolina comes to life once she is exposed to the urban environment, Emilio finds the urban experience so unbearable that he wishes to be out of the light: "Troppa luce! - mormorò egli abbacinato. - Andiamo all'ombra" (Senilità, 48; "'Too much light!' he muttered, dazzled by it. 'Let us go into the shade." Emilio's Carnival, 39)

Emilio cannot tolerate the city street because it exposes Angiolina's essence: an essence that is inextricably linked to the streets of Trieste, which she finds both pleasurable and exhilarating and where she can assert her own power through her gaze. The image of the refined "Ange" that Emilio had constructed is gradually shattered in front of his very eyes and replaced by a more earthly image of a woman aware of her own beauty and power - "La donna ch'egli amava, Ange, era sua invenzione, se l'era creata lui con uno sforzo voluto" (Senilità, 48; "The woman he loved, Ange, was his invention, he had created her himself out of an act of will." Emilio's Carnival, 39) Emilio's confused emotional state coincides with an aimless wandering in the streets: "camminò solo, senza direzione" (Senilità, 48; [He] walked on by himself, heading nowhere." Emilio's Carnival, 40). His inability to dominate his relationship with Angiolina parallels his lack of direction within the urban environment: instead of Emilio leading Angiolina into a bucolic landscape, it is she who leads him astray within the city.

The disorienting essence of Angiolina and Trieste is emphasized when Emilio finds out from Balli that during the first night of Carnival he saw Angiolina with another man. It is not by chance that Svevo introduced the image of the carnival at the moment when he wanted to underscore Emilio's sense of disorientation and lack of control. Bakhtin's comments on carnival can help us to give more depth to this episode of Senilità. Although Bakhtin focussed specifically on Medieval and Renaissance celebrations, his insight is useful in placing this festive phenomenon into a broader interpretive context and can be applied to our text without difficulty. In Bakhtin's words, "carnival celebrated temporary liberation from the prevailing truth and from the established order; it marked the suspension of all hierarchical rank, privileges, norms, and prohibitions. Carnival was the true feast $[\ldots]$ of becoming, change and renewal. It was hostile to all that was immortalized and completed" (Rabelais and his World, 10). 
Moreover, this chaotic, unruly and unorganized festivity that breaks free from the norms and rules of society is inclusive; the carnival is not a spectacle that can be passively observed. On the contrary, everyone is a participant and everyone laughs the same ambivalent laughter, at once triumphant and derisive: "[as it] asserts and denies, it buries and revives" (Rabelais and his World, 12). But for the carnival to be universal, for its laughter to be ubiquitous, it cannot take place in the privacy of one's home. Its locus is the marketplace, the town square where people meet to interact and conduct their businesses. As I have noted before, the open, decentralized, fluid structure of the square embodies the essence of the modern city. A connection between the carnival and the urban environment becomes visible: both are spaces of fluidity and ambivalence. However, an important distinction must be made: while the traditional medieval carnival enacts a momentary disruption that is then reabsorbed within the established hierarchical order, the metropolitan experience negates the possibility of reabsorption. Its essence is centrifugal. In it, one is lost forever.

By inserting the carnival at this point in the novel, it seems that Svevo is interested in highlighting the contradictory and amorphous elements of the modern city, as well as Emilio's inadequacies in dealing with it. The ambivalent nature of the carnival, its breakdown of boundaries, its exaltation of constant becoming and its urban connotation cannot appeal to Emilio, who, as we have seen, is interested in exerting his authority and in maintaining a distance from the chaotic urban space. In fact, Emilio does not participate in the carnival activities. His only reason to go out that night is to find and confront Angiolina, who is taking part in the festivities.

After Balli goes home, Emilio's first reaction is a feeling of self-loss: "non si ritrovò neppure quando fu solo" (Senilità, 91; "he was still unsettled when he was alone again" [Emilio's Carnival, 81). His incapacity to find himself emotionally ("ritrovarsi"), or to decide how to face Angiolina, corresponds to his actual getting lost within the streets of Trieste. His constant change of strategy corresponds to his inability to find the most effective way to address his unfaithful lover. His imagined words turn in fact from "dolci" to "durissime," and finally to "dignitose" (Senilità, 95; "sweet", "most harsh", "dignified") as his plan to find Angiolina makes him move in opposite directions; first he decides to wait for her by the train station, then he decides to catch up with her in Via Romagna, and then, finally, he opts for a different route:

Se essi rincasavano da quella parte, non sarebbe stato più sicuro, per ritrovarli, di salire alla via di Fabio Severo dalla parte del giardino pubblico e discenderne andando loro incontro per via Romagna? (Senilità, 93) 
(If they were going back to Angiolina's from that side of town, would it not be more likely to find them by going up via Fabio Severo from the public gardens and then down via Romagna, thus meeting them head on? [Emilio's Carnival, 83])

However, Emilio's well defined plan (as suggested by the precise topographical information) is not carried out. It is not only his indecision that makes him change his mind so often; he is also befuddled by the city. In the same way that the fixed image of "Ange" cannot contain Angiolina's fluid essence, the exact topographical structure of Trieste does not correspond to the actual city: at the moment when Emilio needs more than ever to rely on the urban plan of the city to reach Angiolina, the very layout of Trieste fails him. The precise, rational course of the city streets reverts to a structure of deception and confusion:

Continuò a camminare con passo celere che presto degenerò in corsa. Vedeva dinanzi a sé un lungo tratto di strada bianca e ricordò che, quando avrebbe girato, ne avrebbe visto un altro altrettanto lungo e poi un altro. Interminabile! (Senilità, 94)

(He continued walking quickly and before long broke into a run. In front of him he saw a long stretch of white street and remembered that when he turned the corner, he would see another equally long, and then yet another. Interminable! [Emilio's Carnival, 84])

The adjective "interminabile" which concludes Emilio's vision of the labyrinthine structure of Trieste underlines his overwhelming sense of disorientation, which is coupled here with Emilio's own physical and mental breakdown. The verb "to degenerate" used to indicate the protagonist's movement in the city, suggests Emilio's weak mental and physical state: as he loses his bearings within the city he also loses his ability to think clearly; his attempt to formulate an impressive last phrase with which to address Angiolina turns into an incoherent scream as he falls and hurts himself. Moreover, during this night of carnival Angiolina becomes for Emilio an ephemeral ghost: "Un riflesso, un'ombra, un movimento, tutto assumeva la forma, l'espressione del fantasma che lo fuggiva" (Senilità, 95; "A reflection, a shadow, a movement, everything took on the shape and demeanor of the phantasm that eluded him" [Emilio's Carnival, 85]). This is the upside down logic of the carnival. Emilio, who believed that he could contain Angiolina's fluid essence, must now recognize his own defeat: "era lui l'individuo strano, l'ammalato, non Angiolina" (Senilità, 96; "He was the weird one, the sick one, not Angiolina" [Emilio's Carnival, 85]). His effort to idealize the woman he loved resulted only in his being covered with 
ridicule. Since he did not take part in the carnival festivities, he cannot rejoice in its gay, ambivalent laughter and so he remains the passive object of someone else's laugh: at the end of the evening he can understand only that "si sentiva deriso" (Senilità, 95; "[he] look[ed] ridiculous in his own eyes" [Emilio's Carnival, 85]). Here lies Svevo's irony. Through the image of the carnival, the author unveils the absurdity of Emilio's behaviour: Emilio seeks to impose rigidity on his urban experiences without realizing that in so doing he becomes its victim. In this sense we can also understand the title of the novel: "Senilità" indicates the lack of flexibility, the inability to take part in the ambivalence and elusive essence of the modern city.

Emilio's inability to possess Angiolina is further emphasized later in the novel, when he is finally able to spend the night with her. In the moment of sexual intimacy, he realizes bitterly that she is still distant, escaping him: "il possesso, la verità? La bugia continuava spudorata come prima ed egli non scorgeva alcun modo per liberarsene" (Senilità, 156; "Possession? Truth? The lie was continuing shamelessly as before and he found no way of extricating himself" [Emilio's Carnival, 143]). It is worth noting that in Svevo's free indirect discourse it is impossible to determine to whose lie he is referring. The text itself, just like the city, remains ambiguous, open to different interpretations: Emilio is possessed by Angiolina's lies just as he is by his own. In fact, he will continue to deceive himself into believing in his own "Ange" and what she tells him. Possession of her body does not bring him closer to her. "Aveva posseduto la donna che odiava, non quella ch'egli amava" (Senilità, 155; "The woman he had possessed was the woman he despised, not the woman he loved" [Emilio's Carnival, 142]). The sexual union does not consolidate their relationship, but only reveals further the lies upon which it is built, exposing the unbridgeable distance between the two lovers. Emilio is unable to understand the woman he loves. She will escape him until the very end of the novel; Emilio will discover her last, colossal lie only after she is gone: I refer to Angiolina's invention of a whole family, the Deluigi, for whom she claimed to work, and whom she used whenever she had to justify her many absences or delays.

This lie is also particularly interesting from a narrative perspective for it conflates a commonality between Emilio and the readers. Although we know, as readers, that Angiolina uses the Deluigis as an excuse every time she is late, or misses an appointment with Emilio, we never question their existence. There is no textual indication that Angiolina has invented them. Thus, at the end of the novel when we find, together with Emilio, that they do not exist, our surprise is similar to his. As Emilio confronts Angiolina's deceitfulness, we too face the misleading construction of the novel. The 
written word, like the urban space it represents, has become a space of potential deception, a labyrinth in which readers must try to find their bearings without necessarily believing they will be able to gain a sense of complete understanding. ${ }^{30}$ The irony of the novel rests in the fact that the unveiling of this lie does not help Emilio, or the readers, gain a better grasp of Angiolina. The shock it provokes is an end onto itself. Its goal is just that: to show that there is a rupture in the text and that Svevo, as a writer of the urban experience, is not interested in reabsorbing it. The task of nullifying the element of shock is left to Emilio, who is unable to exist in the ambivalent, fluid, and deceptive world of Angiolina. After a first moment of shock and anger for having been fooled to such an extent, he will go back to cherish his image of the seraphic "Ange". With this gesture it becomes clear that Emilio is, in Cacciari's words, the mystifier of the urban reality.

Emilio's urban love affair has a disruptive effect even on his private space. The home, perceived by late nineteenth-century urban thinkers as the last refuge in which an organic, harmonious existence is still possible, reveals in fact its own deteriorating qualities, once Angiolina, through Emilio's stories, enters the apartment that he shares with his sister Amalia. Although indirectly, Angiolina is in fact responsible for Amalia's destiny, as Emilio notes bitterly to Balli: "Strano! Angiolina aveva parte nel destino della sorella" (Senilità, 127; "How curious that Angiolina should be playing a part on his sister's destiny" [Emilio's Carnival, 115]). While Angiolina is the woman who belongs to the city, Amalia is closely linked to the domestic sphere. Almost a prisoner in her own house, Amalia has spent her life caring for her brother and their modest apartment, surrounded by "mezzo migliaio di romanzi," (Senilità, 20; "The hundreds of novels" [Emilio's Carnival, 11]) through which she has passively lived the adventures of many heroines. As Saccone noted, it is only in order to compensate the emotional emptiness that she feels once her brother starts ignoring her, that she becomes attracted to Balli. ${ }^{31}$ The interior space is ultimately unable to protect Amalia from the disruptive world of the city. Through Amalia's drama Svevo reveals that the private space is not immune to the disintegrating forces at play in the modern city; its safety is only an illusion. After the reassuring peace of their domestic space has been disrupted,

30 Drawing upon various modernist texts, Faris emphasizes how, "in addition to evoking the labyrinth as a symbol for the city, the mind, and the text, novels like Joyce's Ulysses, Butor's Passing Time, and Robbe-Grillet's In the Labyrinth duplicate the form of the labyrinth in the structural design of the prose so that in them besides the labyrinths in the texts we experience the labyrinths of the texts"; 35 .

31 Saccone, Il poeta travestito, 177-182. 
both Emilio and Amalia find themselves emotionally homeless, walking aimlessly around the city. When Emilio accidentally encounters his sister in one of his endless walks, after the initial shock of seeing her outside, he must admit the similarity of their destinies: "Chissà quale tristezza l'aveva spinta a quella passeggiata in cerca di svago! Egli poteva capirla facilmente ricordando quanto spesso i suoi desideri cacciassero di casa anche lui" (Senilità, 146; "What sorrow could have driven her to seek diversion in that stroll! He could easily commiserate, remembering how often his own frustrations had also driven him out of the house" [Emilio's Carnival, 81).32

The Brentanis' is a bourgeois drama triggered by the nostalgic desire for a world in which relationships are still meaningful. ${ }^{33}$ Stefano Balli, Emilio's best friend, is immune from such a drama. His attitude towards existence is quite different from that of Emilio: he is an experienced womanizer and he is also at home in the urban space. Like Angiolina, he enjoys the urban spectacle; but unlike Angiolina, he attempts to maintain a superior detachment from it. In this sense Balli's actions represent a different approach to the urban space: he is not the man of the crowd; he represents instead a new attitude towards the city which-as we have seen-would be described a few years later by Simmel as that of the blasé individual. For Simmel the only way to maintain a hold of one's individuality in the dehumanizing and excessively stimulating urban environment is through detachment. It is this blasé attitude that leads Balli to perceive both the urban space and his human relations as interchangeable. He is aware of the impossibility of establishing loyal relationships and therefore he perceives both the space he inhabits and the women he meets only as a means to make him feel superior: staring at the Sunday crowds that walk idly on the Corso, he compares them to a swarm of ants (formicaio) who would be disappointed if he did not grace them with his presence: "guai se non fossi venuto [...]. La gente sarebbe tornata a casa delusa" (Senilità, 79; "What a

${ }^{32} \mathrm{On}$ the homelessness of the modern city dweller see also Dal Co, Abitare nel moderno. Commenting on a short story by Herman Hesse, Dal Co notes for instance: "Nessuna patria è destinata al moderno, nessun asilo, pertanto, attende l'abitante della metropoli e nessuna casa può alla fine essere posseduta dal nomade che in essa conduce la propria esistenza"; 11.

33 For a different interpretation of Emilio as a character who at the end "tende al meglio," see Saccone. In his essay on Senilità he writes: "Emilio, dinanzi alla riconosciuta inadeguatezza, anzi deficienza della realtà presente, di sé e degli altri, in vari modi è sempre disposto alla speranza; già, come Zeno, "tende al meglio". È questa insoddisfazione, e tensione al superamento, che forma [...] la problematicità del personaggio, la sua qualità demoniaca"; 175. 
pity if I hadn't come! [...] All these people would have gone home disappointed" [Emilio's Carnival, 69]). Unlike Emilio, he is not prone to idealizations: instead of trying to impose a transcendental meaning on existence, he feels at home in the crowded urban space.

Balli's attitude towards reality also informs his aesthetic ideals. A sculptor, who believes strongly in his artistic abilities, he is a modern artist: a detached, self-absorbed city observer who needs distance in order to give some aesthetic form to the chaotic urban experience. Against the principles of classical aesthetics that attempt to mediate the plurality of existence, he is interested in expressing "a certain ideal of spontaneity" Emilio's Carnival, 8; "un certo ideale di spontaneità"; Senilità, 17) through which he could give form to his aesthetic primitivistic ideals: "the reconquest of simplicity or ingenuity that the so-called classics had stolen from us" Emilio's Carnival, 9; "la riconquista della semplicità o ingenuità che i cosidetti classici ci avevano rubate"; Senilità, 18). Balli wants to express immediate reality without sublimating it. His aesthetic views make him see Angiolina not as the idealized "Ange", but as its opposite, a more earthly, vulgar and sexual "Giolona". And it is "Giolona" that he decides to use as a model for one of his sculptures. The sculptor is interested in representing her as a sinner, in a moment of religious rapture. In Balli's vision, her sensual beauty and her frivolous hairstyle would contrast with "The Prayer expressed by the face" (Emilio's Carnival, 169; "la preghiera che la faccia avrebbe espressa"; Senilità, 182). It seems that Balli wants to represent the intrinsic contradiction of Angiolina, by combining her sexuality and sensual beauty with a pious act. The sculpture would then represent a moment of spiritual transcendence, in which Angiolina's sexuality would be, just for an instant, sublimated by her prayer: "doveva sorgere da quell'argilla una prece, la prece di persona che per un istante crede e che forse non avrebbe creduto mai più" (Senilità, 181; "Out of the clay a supplication was to emerge, the supplication of someone who for one moment believed and might never believe again" [Emilio's Carnival, 168]). The moment of rapture would unveil its very impossibility, bringing to the fore the sense of metaphysical loss that characterizes the human condition. Thus, Balli appears to be very much embedded in a negative perception of existence: he is the artist who embraces lack of meaning without wanting (as Emilio and Amalia did) to fill its void. Yet, his attempt to give aesthetic form to such an idea must fail: Angiolina will not allow herself to be reduced to Balli's perception of her. Her disinterest in posing as if in prayer undermines Balli's artistic idea, because Angiolina keeps "flirting" with God, by maintaining a provocatively sexy look instead of the religious one envisioned by Balli. As a con- 
sequence, the sculpture will never be completed. The detached artist, who thought he could give form to his image of Angiolina, is at a loss. Angiolina, through her playful and irreverent flirting, resists Balli's attempt to reduce her, literally, to matter. In so doing, Angiolina unveils her true essence: not only is she undecipherable, but she is also light; lightness is the quintessential characteristic of Angiolina, the quality that allows her to unveil the fluidity of existence and laugh at the human attempt to weigh it down and contain it within a preconstructed system.

Thus, Angiolina's laughter offers an alternative approach to the urban experience. Whereas the two male figures remain serious in their relation to reality, Angiolina's laugh shows something quite different. She does not take seriously the role that the two men attempt to impose upon her and she laughs both at Emilio's desire to idealize her and at Balli's vulgar vision of her. She is neither the positive, meaningful "Ange", nor the negative, meaningless "Giolona": yet this lack of identity does not give way to a dramatic crisis, as it would with a Pirandellian character. ${ }^{34}$ She could be interpreted instead as Cixous' Medusa who "shatter[s] the framework of institutions, blow[s] up the law, break[s] up the 'truth' with laughter" (888).

In The Book of Laughter and Forgetting, Milan Kundera describes two kinds of laughter. The first kind is the domain of the devil and is characterized by embracing meaninglessness; the second kind, born as an answer to the devil's laughter, is that of the angel's: "whereas the devil's laughter denoted the absurdity of things, the angel on the contrary meant to rejoice over how well ordered [...] and meaningful everything here below was" (86-87). Both kinds of laughter are opposite poles of the same system. One simply negates the other. Angiolina's laughter, however, brings to the fore a third kind of laughter, a lighter one, that escapes being grounded within the framework of the established system, and unveils a different approach to reality. Her laughter is closer to the one posited by Davis in relation to

${ }^{34}$ It is enough to think of Pirandello's Così è se vi pare to realize the difference that separates the two authors in dealing with a similar identity issue. Even Laudisi's laughter, which reflects Pirandello's point of view, cannot be compared to Angiolina's. The former is still embedded in the awareness of impossibility of meaning whereas the latter goes beyond it. Gaetano Cipolla in his study Labyrinth: Studies of an Archetype similarly notes that Laudisi, "doomed to uncertainty in a labyrinthine space, laughs and cries about his own destiny. Before the darkness, his laughter represents the desperation and the nostalgia of the light, the desire to "solve" the knots of the universe and the condemnation to fail"; 121. 
feminist theory: it destabilizes the order of the old tragedians evoked by Nietzsche, and, if only for an instant, "releases the 'feminine' [...] from its binary bondage" (208). It also recalls the Bakhtinian carnival. It unveils "the gay relativity of prevailing truths and authorities" (11). Her refusal to follow the simplest rules of logic is symptomatic of her particular world view. As Emilio notices with dismay, as he catches her in one of her many lies, Angiolina does not believe in logic:

"Era una mentitrice ostinata benché, in verità, non conoscesse l'arte di mentire. Era facile farla cadere in contraddizione. Ma quando tale contraddizione le era stata provata, ella tornava con fronte serena ai suoi primi asserti, perché, in fondo, alla logica non ci credeva" (Senilità, 166)

(She was a stubborn liar despite the fact that she did not possess the art of lying. It was easy to catch her in a contradiction. But when a contradiction was demonstrated to her, she blithely returned to her first assertion since logic meant nothing to her. [Emilios Carnival, 153])

By not taking logic into account, and by showing amused indifference when her contradictions are discovered, Angiolina shows her irreverence towards a rigid construction of existence that attempts to give a systematic interpretation to every experience. As a consequence, even language loses its traditional referentiality. This point is further emphasized in the novel by the use that she makes of both Latin and ecclesiastical phrases which she takes, distorts, and uses with different semantic values, with a profane and comical result that makes her laugh "spudoratamente":

Quando ne aveva assai dei suoi baci, lo respingeva dicendogli: ite missa est, insudiciando un'idea mistica che Emilio serio, serio, aveva espressa più volte al momento di separarsi. Domandava un Deo gratias quando chiedeva un piccolo favore, gridava mea maxima culpa quando egli diventava troppo esigente, libera nos Domine quando non voleva sentir parlare di qualche cosa (Senilità, 37-38).

(When she tired of his kisses, she pushed him away saying: Ite missa est, soiling a mystical notion that Emilio had often expressed with profound sincerity when saying goodbye to her. She would ask for a Deo gratias when she wanted a small favour, shouted mea maxima culpa when he became too demanding, libera nos Domine when she did not want to talk about something. [Emilio's Carnival, 29])

The use Angiolina makes of these phrases in erotic and amorous settings underlines the fact that she is not concerned with their original, religious value, nor is she interested in negating their original significance: the phrases she repeats laughingly have become for her linguistic fragments which have lost any reference to their original meaning. In Angiolina's 
mouth they become a means to playful sexual flirtation, unveiling other, irreverent semantic possibilities. ${ }^{35}$ Yet, when Angiolina uses these religious sentences, Emilio shows quite a strong nostalgic reaction. Viewing it as something that he had willingly removed from his household, he nonetheless feels its absence: "Oh, la dolce cosa ch'era la religione. Da casa sua e dal cuore d'Amalia egli l'aveva scacciata, [...] ma ritrovandola presso Angiolina, la salutò con gioia ineffabile" (Senilità, 37; "Oh, the beauty fo religion. He had banished it from his home and from Amalia's heart [...] but rediscovering it with Angiolina, he welcomed it with ineffable joy." [Emilio's Carnival, 28]). If Emilio's reaction to religion reveals the torment for an unresolved conflict, Angiolina's laughter signifies the overcoming of the conflict itself. She is already elsewhere. In this sense she reveals her ex-centricity, underscored by the fact that, at the end of the novel, she is gone: she has fled to Vienna with a bank clerk, rumour has it, but, as with everything else that concerns her, we cannot be quite sure.

Her laughter becomes emblematic of a new perception of ex-centric, contemporary, urban existence that does not adhere to the nineteenth-century negative interpretation of the modern metropolis. Her laughter truly unveils Nietzsche's "eternal comedy of existence" and brings to the fore a spirit of lightness necessary to manage the contradictions of urban space, a spirit that is closely linked to the one expressed in the carnival. The city's fluidity cannot be overcome, but it becomes possible, once one renounces the constricting solidity of normative boundaries, to embrace its multifaceted, labyrinthine reality. Angiolina's lightness reveals Svevo's aim throughout this and other novels: to underscore the fluidity and elusiveness of experience, along with its hidden, multiple possibilities. When Emilio dreams of a beautiful but sad and serious Angiolina-"Sì! Angiolina pensa e piange!" (Senilità, 250; "Yes! Angiolina thinks and weeps" [Emilio's Carnival, 233])-he feels the need to silence her laughter, because it unveils his inadequacies in dealing with a world that he is unable to control. Yet her laughter, precisely because it has been silenced, resounds even louder than before, filling the narrative space, unveiling the ambiguities of existence, casting doubt upon everything that appears solid, truthful, and serious, ultimately revealing that the narrative praxis better suited to the metropolitan experience is the one that embraces and attempts to give voice to its ex-centricity.

Purdue University

West Lafayette, IN

${ }^{35}$ See also Biasin, "Un Deo Gratias qualunque." 


\section{Works cited}

Apih, Elio. Trieste. Bari and Rome: Laterza, 1988.

Ara, Angelo and Claudio Magris. Trieste, unidentità di frontiera. Turin: Einaudi, 1982.

Bakhtin, Mikhail M. The Dialogic Imagination. Four Essays, ed. Michael Holquist, trans. Caryl Emerson and Michael Holquist. Austin, TX: University of Texas Press, 1981.

—. Problems of Dostoevsky's Poetics, trans. R.W. Rotsel. Ann Arbor, MI: Ardis, 1973.

Rabelais and His World, trans. Hélène Iswolsky. Bloomington, IN: Indiana University Press, 1984.

Barilli, Renato. La linea Svevo-Pirandello. 2nd ed. rev. Milan: Mursia, 1977.

Baudelaire, Charles. Selected Writings on Art and Literature, trans. P.E. Charvet. New York: Penguin Books, 1972, 1992.

Benedetti, Laura. "Vivere e essere vissuti: Amalia in Svevo's Senilità." Italica, 68 (1991): 204-216.

Benjamin, Walter. Charles Baudelaire: A Lyric Poet in the Era of High Capitalism, trans. Harry Zohn. London: NLB, 1973.

Biasin, Gian Paolo. "Un Deo Gratias qualunque: Svevo, il linguaggio, il sapere." Italica, 61 (1984): 134-146.

Borghello, Giampaolo. La coscienza borghese. Un saggio sulla narrativa di Svevo. Rome: Savelli, 1977.

Butler, Judith. Gender Trouble. Feminism and the Subversion of Identity. New York: Routledge, 1999.

Cacciari, Massimo. Metropolis. Saggi sulla grande città di Sombart, Endell, Scheffler e Simmel. Rome: Officina Edizioni, 1973.

Cipolla, Gaetano. Labyrinth: Studies on an Archetype. Ottawa-Toronto-New York: Legas, 1987.

Cixous, Hélène. "The Laughter of the Medusa." Signs, 1 (1976): 875-893.

Dal Co, Francesco. Abitare nel moderno. Rome: La Terza, 1981.

Davis, D. Diane. Breaking Up [At] Totality. A Rhetoric of Laughter. Carbondale, IL: Southern Illinois University Press, 2000.

Faris, Wendy B. "The Labyrinth as Sign" pp. 33-41 in City Images: Perspectives from Literature, Philosophy and Cinema, ed. Mary Ann Caws. New York: Gordon and Breach, 1991.

Federici, Corrado. "L'eccentricità e l'ex-centricità dei protagonisti sveviani", pp. 51-62 in Italo Svevo tra moderno e postmoderno, eds. Mauro Buccheri and Elio Costa. Ravenna: Longo, 1995.

Felski, Rita. The Gender of Modernity. Cambridge, MA: Harvard University Press, 1995.

Frisby, David. Cityscapes of Modernity. Critical Explorations. Cambridge, UK, and Malden, MA: Polity Press, 2001.

Gilman, Sander. Disease and Representation. Images of Illness from Madness to AIDS. Ithaca, NY: Cornell University Press, 1988. 
Irigaray, Luce. This Sex Which Is Not One, trans. Catherine Porter with Carolyn Burke. Ithaca, NY: Cornell University Press, 1985.

Kundera, Milan. The Book of Laughter and Forgetting, trans. Aaron Asher. New York: Harper Perennial, 1996.

Le Bon, Gustave. The Crowd: A Study of the Popular Mind, intro. Robert K. Merton. New York: The Viking Press, 1960, 1962.

Leone De Castris, Arcangelo. Italo Svevo. Pisa: Nistri-Lischi, 1959.

Lombroso, Cesare and Guglielmo Ferrero. La donna delinquente, la prostituta e la donna normale. Turin: L. Roux, 1893.

Maier, Bruno. Italo Svevo. 4th ed. rev. Milan: Mursia, 1975.

Mantegazza, Paolo. Il secolo nevrosico. Florence: Barbera, 1887.

Nietzsche, Friedrich. The Gay Science. With a Prelude in Rhymes and an Appendix of Songs, trans. Walter Kaufmann. New York: Vintage, 1974.

Nordau, Max. Degeneration, trans. George L. Mosse. Lincoln and London: University of Nebraska Press, 1993.

Parsons, Deborah L. Streetwalking the Metropolis: Women, the City and Modernity. Oxford: Oxford University Press, 2000.

Pirandello, Luigi. Il fu Mattia Pascal. Milan: Mondadori, 1988. Liolà. Cosi è (se vi pare). Milan: Oscar Mondadori, 1970.

Saba, Umberto. Prose. Milan: Mondadori, 1964.

Saccone, Eduardo. Il poeta travestito. Otto scritti su Svevo. Pisa: Pacini Editore, 1977.

Showalter, Elaine. Sexual Anarchy: Gender and Culture at the Fin de Siècle. New York: Viking, 1990.

Simmel, Georg. On Individuality and Social Form. Selected Writings, ed. Donald N. Levine. Chicago: University of Chicago Press, 1971.

- The Philosophy of Money, trans. Tom Bottomore and David Frisby. London: Routledge \& Kegan Paul, 1978.

Georg Simmel on Women, Sexuality, and Love, trans. and intro. Guy Oakes. New Haven: Yale University Press, 1984.

Slataper, Scipio. Lettere triestine: col seguito di altri scritti vociani di polemica su Trieste. Trieste: Edizioni Dedolibri, 1988.

Svevo, Italo. La coscienza di Zeno. Milan: Dall'Oglio, 1938, 1982.

Emilio's Carnival. (Senilità), trans. Beth Archer Brombert. New Haven and London: Yale University Press, 2001.

Senilità. Milan: Dall’Oglio, 1938, 1982.

Tönnies, Ferdinand. Community and Association, trans. Charles P. Loomis. London: Routledge and Paul, 1955.

Van Vucht Tjissen, Lieteke. "Women between Modernity and Postmodernity" pp. 147-163 in Theories of Modernity and Postmodernity, ed. Bryan S. Turner.

London and Newbury Park: Sage Publications, 1990.

Weininger, Otto. Sex [and] Character. New York: G.P. Putnam's Sons, 1906. 